Diffusion of personalised services among Dutch municipalities: evolving channels of persuasion

Paper submitted to Local Government Studies

Vincent Homburg (corresponding author)

Erasmus University Rotterdam

Faculty of Social Sciences, Public Administration, Comparative Public Services

Innovation

PO Box 1738

NL3000 DR Rotterdam

The Netherlands

Phone +31 104081863

Email: homburg@fsw.eur.nl

Andres Dijkshoorn

Erasmus University Rotterdam

Faculty of Social Sciences, Public Administration, Comparative Public Services Innovation

PO Box 1738

NL3000 DR Rotterdam

The Netherlands

Phone: +31 104082526

Email: dijkshoorn@fsw.eur.nl

Marcel Thaens

Erasmus University Rotterdam

Faculty of Social Sciences, Public Administration, Comparative Public Services

Innovation

PO Box 1738

NL3000 DR Rotterdam

The Netherlands

Phone: +31 104082331

Email: thaens@fsw.eur.nl

Main text (including tables and figure, excluding footnotes and references): 6109 words 


\title{
Diffusion of personalised services among Dutch municipalities: evolving channels of persuasion
}

\begin{abstract}
In many European countries, municipalities are becoming increasingly important as providers of electronic public services to their citizens. One of the horizons for further expansion is the delivery of personalised electronic services. In this paper, we describe the diffusion of personalised services in the Netherlands over the period 2006-2009 and investigate how and why various municipalities adopted personalised electronic services. In achieving this, we analyse data that were gathered during interviews with key stakeholders in ten selected Dutch municipalities. We synthesise the findings in an explanatory model of personalised electronic service delivery diffusion. The model emphasizes persuasive pressures that are channelled to potential adopters of personalised services. Furthermore, the model shows how persuasive pressure (as perceived by adopters) is followed-up by organisational search activities, and how, in various circumstances, the idea of personalised services is 'framed' by innovation champions, knowledge brokers and new members of staff as to appeal to specific organisational priorities and ambitions. In doing so, this article contributes to an institutional view on adoption and diffusion of innovations, in which (1) horizontal and vertical channels of persuasion and (2) human agency, rather than technological opportunity and rational cost-benefit considerations, account for actual diffusion of innovations.
\end{abstract}

\section{INTRODUCTION}

The use of information and communication technologies (ICTs) is central in many national policies as the means to actually realise government modernisation and transformation agendas. In many western countries, it is especially local governments that are developing one-stop shops that serve as a point-of-entry to the whole range of government (Ling, 2002; Ho, 2002; BeynonDavies and Martin, 2004; Mulgan, 2005) in such a way that the relationship between public sector organisations and citizens is re-engineered (BeynonDavies and Martin, 2004). This redesign phenomenon has been termed electronic government (Bekkers and Homburg, 2005).

Internationally, the actual implementation and take-up of the e-government phenomenon by public sector organisations has lagged behind policy ambitions. In trying to explain the actual diffusion of e-government, various empirical studies have identified city size, citizen demand, organisational structure, geographic location and capacity (see Table 1 for details of the literature reviewed) as the most important determinants of e-government adoption by public sector organisations.

\section{--- Table 1 somewhere 1}

Although useful in itself, these determinants do not provide insights into questions such as why public sector organisations actually adopt (or fail to adopt) e-government innovations, and how such organisations actually learn to 
innovate. Further, theoretical insights such as Orlikowksi's (2000) practice lens, Cziarniawska and Sevon's (2005) travelling of ideas, Bekkers and Homburg's (2005) information ecology of e-government and Homburg and Georgiadou's (2009) technological 'contact infection' point towards human agency and institutional pressures as potential explanations for the variance in the prevalence of e-government services among populations of public sector organisations. Zorn et al. (2011) have argued that, especially for non- and notfor-profit organisations, technological innovations are a means for establishing legitimacy in the eyes of key stakeholders as much as they are means for enhancing operational efficiency. Further, and related to this, Frumkin and Galaskiewicz (2004) indicate that institutional pressures to adopt specific innovations are very relevant for public sector organisations.

Our hope is that, by focusing on 'agency' alongside 'structure' (Orlikowksi and Barley, 2001), more light will be shed on the process of technological and organisational change (Pettigrew, 1985) such that, eventually, the diffusion of egovernment will be better understood. This paper seeks to examine the diffusion of a specific, fairly mature form of e-government, namely personalised egovernment, in a specific setting (municipalities in the Netherlands). The analysis reported in this paper extends the existing literature on e-government to include both 'agency' and 'process' aspects of e-government innovation.

\section{PERSONALISATION AND PERSONAL PUBLIC SERVICE DELIVERY}

Various authors have argued that various 'stages' or 'levels of maturity' can be discerned in electronic service delivery (Layne and Lee, 2001; Anderson and Henriksen, 2005), ranging from public organisations offering one-way transmission of static information, through organisations offering online transactions, to organisations offering integrated services (which incorporate information from sources external to the organisation and through which the citizen may interact in the first place). A supposed characteristic of the 'final stage' in these maturity models is that there is a seamless integration of information services across administrative boundaries.

Recently, the idea of integration was further pushed by it being given strong support (OECD, 2009) and the related academic discussion of personalised integrated services (King and Cotterill, 2007; Peterson et al., 2007; Homburg and Dijkshoorn, 2011). A characteristic of personalised services is that they generally, when using Customer Relationship Management systems (King and Cotterill, 2007), make use of authorisation, profiling and customisation in such a way that, eventually, one-to-one relationships between public service providers and citizens are established. One-to-one relationships may provide citizens with, for example, pre-filled forms, suggestions for permits or benefits that maybe relevant given past requests, automatically generated reminders, and news updates based on customer preferences. The eventual aim is to provide services that are geared towards the needs of citizens, and less towards the existing supply-oriented organisational routines of service providers.

Examples of personalised services at national or federal levels are the Belgian MyMinFin e-tax initiative, the Danish borger.dk portal, the Estonian eesti.ee 
initiative, the French mon.service-public.fr website, the Norwegian Norway.no portal, the British direct.gov.uk site and the Dutch mijnoverheid.nl site. In the Netherlands, various municipalities offer personalised sections on their websites including http://www.eindhoven.nl/mijn-eindhoven.htm for the city of Eindhoven, and http://www.rotterdam.nl/mijn_loket_digid for Rotterdam.

Implementing personalised electronic government services is far from trivial and the literature reports many obstacles. These include socio-political problems of information sharing across traditional organisational boundaries (Mulgan, 2005; Homburg, 2008), the existence of legacy systems (Pieterson et al., 2007) and concerns related to privacy issues (Lips et al., 2004).

In this paper, we are not arguing that personalised e-government service delivery is, or should be, a necessary next step, nor do we intend to discuss whether personalisation should or should not be adopted by public sector organisations. Rather, we analyse personalised e-government services as a 'case' of the diffusion of a specific innovation and analyse how the diffusion of personalised e-government service delivery takes place. In order to be able to explain the diffusion, we focus on a population of 441 potential adopters in a single national jurisdiction, the Netherlands, which can be seen as a decentralised unitary state (Esping-Andersen, 1990; Pollitt and Bouckaert, 2004). Dutch municipal governments are relatively autonomous vis-à-vis central government with respect to management issues, including the design, implementation and maintenance of electronic services (van Os, 2011). In practice, however, various initiatives exist that are aimed at coordinating egovernment development. For instance, the ICTU Foundation is an outreach initiative, governed jointly by the national Ministry of the Interior and Kingdom Relations and the Association of Dutch Municipalities, which attempts to facilitate and support all kinds of public organisations including municipalities in deploying ICTs. In specific policy sectors, initiatives (such as the BKWI in the social security and welfare domain) exist in which local and central governments cooperate in the development of electronic services. At the same time, municipalities cooperate in the context of outreach initiatives such as DIMPACT to share knowledge and to collectively purchase services, hardware and software. These initiatives and organisations are mentioned here to illustrate that although municipalities are relatively autonomous, the development and management of ICTs, including electronic services, does not take place in a vacuum and that therefore explanations that explicitly include contexts might be relevant in explaining the diffusion of personalised e-government services (King et al., 1994).

\section{RELATED RESEARCH: THE THEORETICAL ANTECEDENTS OF DIFFUSION}

Diffusion of a new idea, product or service is defined as the spread of its use in a population of potential adopters (Rogers, 1995; King et al., 1994). The process of diffusion has been linked to characteristics of the innovation itself, the social system (community of potential adopters), channels of communication, and time (Rogers, 1995; Mahajan and Peterson, 1985). Given the lack of a rigorous theory that acknowledges the embeddedness of e-government diffusion processes by municipalities in the larger context of governance (including central-local relationships and the activities of outreach programmes), we scanned and 
searched related concepts in the organisational sociology and institutional theory disciplines - two related literature streams that explicitly address how organisations absorb prevailing ideas from their environments into their operations and structures. However, this literature tends to be relatively abstract, and does not address the diffusion of personalised e-government in the specific context of municipalities.

Advancements in the discipline of organisational sociology in recent decades, such as the emergence of 'new institutionalism' (DiMaggio and Powell, 1983; Tolbert and Zucker, 1996), have highlighted the significance of the professional and/or legal rules, cognitive structures, norms and the prevailing values in which innovation takes place. Institutionalism holds that the adoption of innovations does not take place because individuals or (private as well as public) organisations make rational, calculated decisions regarding costs and benefits (see, for instance, Venkatesh et al., 2003), but rather that:

(1) decisions whether or not to adopt innovations are influenced by rules, conventions, principles, belief systems and social context criteria, and

(2) attempt to shape and affect these overarching structures of norms, beliefs and rules that together form the concept of institutions.

DiMaggio and Powell refer to these kinds of decisions as 'collectively rational', as opposed to individually rational, because the rationality involved in the decisionmaking processes is influenced through information provided by others. Hence, institutionalism emphasises the persuasive control over the practices, beliefs and belief systems of individuals or organisations through an institution's sway (Kimberley, 1979, in King et al., 1994). Persuasion can be achieved not only through directives, but also through more gentle but nevertheless potentially convincing means such as deploying specific knowledge, subsidising activities deemed 'appropriate' by national government, standard-setting, raising awareness and generally promoting specific technologies (King et al., 1994). Moreover, Venkatraman et al. (1994) have stated that persuasion can occur both through vertical channels of communication (initiated by actors outside the set of potential adopters, such as central government; see also Leonard-Barton and Rogers, 1981; Moon and Bretschneider, 1997; Bobrowski and Bretschneider, 1994) as well as through processes of mimicking and 'word-of-mouth' diffusion (Wang and Doong, 2010) involving communication, interaction and persuasion among potential adopters (DiMaggio and Powell, 1983). Innovation through mimicry is likely to occur when innovations are socially visible (Mahajan and Peterson, 1985; Dos Santos and Peffers, 1998), when causes, conditions and consequences are known (absence of causal ambiguity, Barney, 1991; Loh and Venkatraman, 1992) and when the success of the innovation is unlikely to be determined by path dependencies (Barney, 1991; Loh and Venkatraman, 1992). The organisational sociology and institutional theory literatures are helpful in identifying an organisation's environment as a source of 'pressure' for organisations to behave in a particular way. Nevertheless, these literature streams do not explicitly address how, through 'pressure', innovations are diffused among organisations. Additional theoretical guidance related to this issue is provided by the so-called Scandinavian Institutionalism (Czarniawska and Sevon, 2005). This school of thought sees innovations as 'ideas' insofar as 
they can be viewed as artefacts. In order for ideas (such as 'personalisation') to spread (using either horizontal or vertical channels of communication) they must be translated into, or associated with, a success story, image or even a myth. During its travel, the idea itself is likely to change (Czarniawska and Sevon, 2005). As such, the idea of translation is a much more complex concept than the notions of 'diffusion, 'adoption, 'mimicry' and 'direction' suggest, and involves various phases in which so-called change agents (Caldwell, 1996) are actively engaged in the process of adoption. Agency in the process of translation takes place in horizontal as well as vertical modes of persuasion, and change agents (experts, boundary-spanning agents, consultants, knowledge brokers etc.) may operate on both the supply and the demand sides of the translation (King et al., 1994).

To sum up, we draw on concepts selected from organisational sociology and institutional theories that are relevant to the diffusion of a specific instance of egovernment. The general sociological and institutional literatures sensitise us to horizontal and vertical 'persuasive' pressures, in the form of beliefs, cognitive structures, norms and values, that are put on municipalities to adopt specific innovations (including e-government). Scandinavian Institutionalism adds the aspect of 'agency' to this: diffusion is not a deterministic process but an intricate social process that involves translation activities by experts, boundary-spanning agents and knowledge brokers. At this moment, however, there is no complete theory available that fully explains the diffusion process. In the analysis section of this paper, we attempt to provide a diffusion model that takes account of the above notions of change.

\section{METHODS AND DATA}

In order to explain the diffusion of personalised e-government services, we first define our population of interest, that is, the set of potential adopters of the innovation being scrutinised: personalised e-government. We chose to analyse diffusion within one national jurisdiction (in our case, the Netherlands), and our first step was to describe the diffusion pattern of personalised e-government services over a four-year period (2006-2009) delineated by two consecutive municipal elections. For this purpose, we used an existing dataset that is assembled annually by the Dutch 'Government has an answer' project. This project monitors directly observable characteristics of e-government initiatives by Dutch ministries, provinces, municipalities and water regulatory authorities, and annually reports its findings. This monitor resembles the practice of UK local government league tables; for American examples refer to McClure et al. (2000).

In line with our objective to further extend the e-government body of knowledge (that is, to actually build theory), we first described general trends in a population of 441 municipalities ${ }^{1}$ and then, as a second step, we selected ten municipalities for an in-depth analysis of adoption processes. As the egovernment literature consistently reports city size as being a major determinant of e-government adoption (see Table 1; see also Reddick, 2004),

\footnotetext{
${ }^{1}$ In the interval 2006-2009, the population of municipalities shrunk from 458 to 441 due to planned mergers
} 
from the 2008 data we selected both adopters ('early adopters') as well as nonadopters ('laggards') from substrata, based on city size, of the population (see Appendix A for a list of the selected municipalities). In each of the selected municipalities, qualitative interviews were held with key stakeholders such as council members, city managers, senior ICT managers and managers of public service provision. The starting point for the interviews was a topic list (see Appendix B) through which it was attempted to identify the antecedents, critical events, ongoing activities and interactions with internal and external stakeholders in relation to e-government and public service delivery. All the interviews were recorded, transcribed and analysed ${ }^{2}$ using back-and-forth coding techniques ${ }^{3}$ (Miles and Huberman, 1994; Patton, 2002). Following recommended practices for qualitative research, data analysis was conducted in parallel with data gathering, starting with the constructs that emerged from the theoretical antecedents of diffusion. In an iterative process, construct categories were refined, added or combined, and new categories sometimes led to new constructs being identified in the empirical data. Furthermore, the five 'nonadopter' cases were compared to the 'adopter'cases based on the occurrence of specific, coded constructs or themes. As a final step, using both theoretical plausibility and induction, relationships between constructs were made explicit: first through 'conjectures' (statements that, through induction, follow from empirical observations, patterns and theoretical analogy), and second through including concepts and relationships in a conceptual framework for understanding the adoption of personalised e-government.

\section{ANALYSIS: EXPLAINING THE DIFFUSION OF PERSONALISED E- GOVERNMENT}

Description of personalised e-government services in Dutch municipalities Table 2 lists the prevalence of certain attributes of personalised electronic service delivery by Dutch municipalities in the years 2006, 2007, 2008 and 2009. Overall, in the period covered, there is an increase in the offered possibility of using DigiD ${ }^{4}$ authentication (from $20.7 \%$ in 2006 to $88.2 \%$ in 2009) and on-line payments (from 15.9\% in 2006 to $80 \%$ in 2009). The growth of possibilities for receiving personalised newsletters, using pre-completed forms, assessing personalised policy consequences and using personalised counters lagged somewhat.

\section{--- Table 2 somewhere here}

Pressure: persuasive influence on adoption decisions

We identified various categories of pressure (see Table 3 ) as sources of 'pressure' on decisions to adopt personalised e-government services. Most prominent was the perceived expectations of citizens. As one councillor phrased

\footnotetext{
2 Note that the interviews were held in Dutch; the authors have translated the quotations given in the analysis section into English.

${ }^{3}$ Using the MaxQDA qualitative analysis tool.

${ }^{4}$ DigiD stands for Digital Identity. With a DigiD users can access a large number of online services offered by Dutch (central and municipal) government agencies.
} 
“... a clamour for service provision, less bureaucracy, transparency: that is external pressure, as I perceive it. (...) Simply because society does not tolerate other kinds of organisational behaviour ..." (Councillor)

Another form of influence that was mentioned quite frequently was the existence of benchmarks against which municipalities can be judged. Several respondents indicated that low performance resulted in questions from, for instance, city council members, especially when neighbouring or otherwise comparable municipalities scored considerably higher ('peer rivalry'). As a manager of service provision explained:

"To score well is felt to be important within municipalities. How often is your municipality mentioned in professional journals, are you in the Top 3.... that is considered to be very important" (Manager of service provision)

The fact that municipalities keep a sharp eye on benchmarks and rankings sometimes results in somewhat perverse incentives to adopt personalised services, such as one respondent noted:

"Our decision to implement personalised service delivery was due to our low ranking ... Our councillor wanted to improve our ranking, and we found out that we could improve our ranking quite easily by implementing a Personalised Internet Page ... and so we did" (Project manager).

To summarise, what can be witnessed is that, in line with institutional theory (DiMaggio and Powell, 1983; Ashworth et al., 2009; Lai et al., 2006), all the municipalities reported perceiving persuasive pressure to adopt personalisation measures, both from outside the set of potential adopters (referring to norms to conform to citizens' needs, or to be receptive towards national initiatives) as well as from within the set of potential adopters (referring to the norm to excel in relation to one's peers). Adopters are associated with a higher perceived persuasive pressure than non-adopters. A notable exception here is legislation as a source of pressure. Legislation here refers to regulations that enable the issuance of integrated permits based on a range of acts (such as the WABO: an act on general environmental issues). Although this regulation does not force personalised service delivery, municipalities reported that they expected it to be easier to comply with future audits and assessments if they adopt personalised electronic services. As one council member explained:

"The WABO describes how we should comply and what kind of checks, audits and assessments are in place. In the end, there is less space to manoeuvre" (Councillor).

Implementing technology in anticipation of future audits has also been reported by Svensson (2002) in a study on the adoption of legal expert systems in municipal social security systems. In our study, pressure from legislation was also reported, although non-adopters reported this more frequently than 
adopters. Legislative pressure therefore cannot explain the adoption of personalised e-government.

--- Table 3 somewhere here

Organisational search: scanning for knowledge, experiences and courses of action Respondents from the municipalities reported that perceptions of persuasive pressure were followed by organisational searching and scanning activities, through which municipalities attempted to seek, identify and choose relevant knowledge, experiences and courses of action (see also Levinthal and March, 1982; Tidd et al., 2009). One respondent clearly illustrated how municipalities react to pressure:

"One member of our support staff made an inventory of associations that staff members are participating in, and she managed to compile a list of three or four pages..." (Manager of service provision)

Typical targets for search and scan operations are forums and national outreach programmes, companies and financial institutions, other municipalities generally, municipalities with which the municipality has an alliance, and within the organisation itself (see Table 4).

--- Table 4 somewhere here

Respondents reported that pressure did not directly result in new connections with other organisations, but rather that it resulted in more intensive contact with forums and associations (for instance, the Public Service Provision Managers' Association, the Association of Dutch Municipalities, and also outreach programmes such as GovUnited and DIMPACT) with which one was already involved. As one public manager reported:

"We meet each other at meetings of municipalities with 100 000+ residents. One talks to others, exchanges experiences, we report our practices, and listen to other ideas ... in this way, we converge on similar solutions as we all offer similar services" (Manager Population Affairs and Taxes)

One respondent explained how one's own organisation could serve as a source of relevant knowledge (see also Isabella, 1990):

"It happened partly due to one of our developers (...) She said she had knowledge of how personalised counters could be implemented but, until then, she had no time to work on them. She said it could be realised given that we already owned the necessary software packages - and she could develop it further. So we felt we were quite lucky to have such a developer who was able to build these facilities..." (Programme manager)

To summarise, in all the selected municipalities we witnessed how pressure was followed by organisational search activities, both in the external environment, as well as in existing alliances and within one's own organisation for solutions and 
inspiration that might already be available. It can also be concluded that both adopters and non-adopters seek and scan for relevant knowledge in national forums, outreach initiatives and companies, but that adopters more frequently report seeking out ideas, inspiration and solutions in alliances, other (often similar) municipalities and their own organisation than non-adopters do.

Framing: translating pressure into local priorities and opportunities According to Sahlin and Wedlin (2008; see also Silva and Hirscheim, 2007), and in line with the Scandinavian Institutionalism mentioned in the discussion on theoretical antecedents of diffusion, knowledge and ideas cannot simply be transfused from one organisation to the other: rather, ideas, concepts and knowledge has to be repackaged and re-embedded (Isabella, 1990; MacDonald, 1995; Sahlin and Wedlin, 2008). In our field study, respondents explained that comparable ideas and 'chunks' of knowledge on personalisation were framed completely differently in various adopting organisations. Personalisation was sometimes framed in terms of:

- A precursor to an organisation becoming a service champion (enabling genuine citizen-centric service delivery);

- A means for achieving efficiency ("If the processes are well-organised, I am convinced that in the long run we can do without large numbers of staff", Councillor);

- Boosting reputation ("We think that we, being part of a high technology region, are obliged to modernise our service delivery", Head of Customer Relations Department); and

- Exerting control ("Now the focus is on the front office ... but in the near future we intend to reengineer processes in the back office as well, so as to simplify and speed up processes...", Project Manager Service Delivery).

Table 5 summarises these assessments.

--- Table 5 somewhere here

Overall, we conclude that persuasive pressures are actively framed by stakeholders so as to appeal to local priorities and ambitions, which are found to be enhancing citizen orientation, organisational efficiency, reputation and management \& control. Adopters differ from non-adopters in terms of the first three framings (being a service champion, striving for efficiency and reputation enhancement), but not in terms of the fourth (management and control).

Activation triggers: enabling episodic changes

From the transcripts of the various interviews, we distilled concepts that did not directly affect adoption but that, nevertheless, can be interpreted as being important in explaining adoption. Activation triggers of various kinds (coined discrepant events by Tyre and Orlikowksi (1994); see also Kim (1998); Zahra and George (2002); Tidd et al. (2009)) were reported by respondents as moderating the impact of persuasive pressures. Van Waarden and Oosterwijk (2006) see activation triggers as precursors of episodic as opposed to more linear forms of diffusion. In our study, we came across general shocks, staff changes and organisational mergers as activation triggers (see Table 6). 
--- Table 6 somewhere here

One clear example of an activation trigger was a firework factory exploding in the municipality of Enschede. This triggered a political crisis and, in the subsequent reorganisation, personalised service delivery was seen as an opportunity to help shape the new organisation. Respondents also mentioned new members of staff. As one respondent explained:

"With new members of staff, new ideas and new energy entered our organisation (...). A new city manager, ICT developers, new departmental managers: they all managed to get up to speed with evolving developments" (Head of Service Delivery)

The merging of municipalities was also reported as a trigger event that helped boost ongoing developments. The idea of service delivery in general, and the more advanced forms of personalised e-government in particular, were embraced by some stakeholders as helping to shape the identity of a new municipal organisation and to get away from the pre-existing local identities of the former smaller municipalities. The above activation triggers were reported more often by respondents from adopting councils than by respondents from non-adopters (see Table 7).

Social integration mechanisms: translating and framing by actors From fieldwork observations, and informed by our theoretical discussion of Scandinavian Institutionalism, we could see that translation, transfusion and repackaging of knowledge and ideas does not take place in a vacuum, but is a social integration process in which specific actors play a role (Czarniawska and Sevon, 2005; see also Pawlowski and Robey, 2004). Szulanski (1996, p. 29) states that "as time passes, a shared history of jointly utilizing the transferred knowledge is built up in the recipient, actions and actors become typified, and types of actions are associated with types of actors".

The actual framing, transformation and transfusion of ideas and knowledge, that occurs between the processes of organisational searching and scanning and the framing of ideas, involves various social integration processes. An example was given by one respondent who commented:

"... John Doe, of Consulting Inc 5 , he is a remarkable character. He has access to senior management levels, where normally no-one understands the potential of modern ICTs. However, he is able to come up with brilliant applications, stories and examples..." (Programme manager)

\footnotetext{
${ }^{5}$ The names of the respondent and the consultancy firm have been changed to maintain anonymity.
} 
In our study, we identified three types of social integration: activities by in-house innovation champions, activities involving knowledge brokers and staff exchanges (see Table 7).

--- Table 7 somewehere here

The importance of innovation champions can be illustrated through a quote by a departmental manager who described the activities of a specific stakeholder as follows:

"... I think it all depends on the person. The former manager of Employment, Welfare and Income, she really was a citizen-and service-oriented person. She really put quite some energy into the whole idea of service delivery. She asked me to team up with her, and to manage a service delivery programme. Then, a whole bunch of enthusiastic people joined us... this group of people, who were all actively participating in the Super Pilots, continued to grow..." (Departmental Service Operations Manager)

Another respondent similarly mentioned a specific innovation champion:

“...the idea of personalisation, that was more or less Erik's business. Our councillor was never a digital enthusiast, and despite limited resources we managed to make things happen. And that was due to the persistence of Erik, who kept on fighting, although the councillor said that he'd never succeed..." (ICT policy advisor).

Staff exchange was also mentioned as a moderator of adoption. One respondent explained:

“... We moved on when a member of Enschede's staff temporarily joined our organisation. Due to personal circumstances, he was able to stay for a while in the Province of Noord-Brabant and we were able to make use of his experience. That helped quite a lot" (Departmental Manager Service Operations).

It is especially through these kinds of integration mechanisms that ideas and knowledge are actually transfused, translated and framed rather than merely being imitated (Howell and Shea, 2001; see also Bressant and Rush, 1995; Rice and Rogers, 1980; Sahlin and Wedlin, 2008; Silva and Hirscheim, 2007). Concluding, we infer that genuine framing, transfusion and translation of knowledge, experiences and ideas takes place through social integration mechanisms, activities of internal innovation champions and external knowledge brokers, and through staff exchange. These activities were more frequently mentioned by adopters than by non-adopters.

\section{SYNTHESIS: CONJECTURES AND EXPLANATORY MODEL}

The findings from this study provide a detailed account of how persuasive pressure is channelled within organisations, and of how various processes (searching and seeking, framing) and moderators (external shocks, social 
integration) are related to the adoption of personalised electronic service delivery.

Processes and moderators, as identified in and distilled from the presented empirical data, can be summarised in a number of conjectures (King et al., 1994) and presented graphically in a model that displays the processes of persuasion at work.

Our first conjecture relates to the concept of environmental pressure. In all our interviews, respondents reported perceiving persuasive pressure from their respective environments (perceived expectations of citizens, legislation, 'naming and shaming' pressure from benchmarks, general considerations relating to the reputation of municipalities, effects of national programmes and peer rivalry) in forms that promote electronic service delivery. However, this perceived pressure was more prevalent in adopters than in non-adopters, leading to the following conjectures:

Conjecture 1A: Municipalities experience environmental pressures that persuade them to adopt personalised electronic service delivery.

Conjecture 1B: Perceptions of persuasive pressure are reported more frequently by adopters than by non-adopters.

In general, persuasive pressure was followed up by organisational searching and scanning activities, through which stakeholders in municipalities attempt to gather knowledge, inspirations and suggestions for courses of action both from the organisational environment (forums and outreach activities, companies, other municipalities in general and allied municipalities in particular) as well as from within their own organisation. In all cases, respondents reported scanning and searching activities, albeit more frequently by adopters than by nonadopters. This leads to our second pair of conjectures:

Conjecture 2A: Municipalities respond to persuasive external pressure by searching and scanning for knowledge, inspiration and suggested courses of action related to personalised electronic service delivery.

Conjecture 2B: Searching and scanning activities are more prevalent in adopters than in non-adopters.

In the various selected municipalities, it could be observed that persuasive pressure and the knowledge and ideas sought were actively 'framed' as compelling arguments for adopting personalised e-government services. Active framing was reported more frequently in adopting organisations than in nonadopting organisations; leading to our third pair of conjectures:

Conjecture 3A: In municipalities, persuasive pressure and sought knowledge are actively framed in order to legitimise the adoption of personalised egovernment. 
Conjecture 3B: Framing occurs more frequently in adopters than in nonadopters.

With these three pairs of conjectures, the processes underlying the adoption of personalised e-government have been identified. In an inductive fashion, moderating influences could also be observed. The first moderating influence relates to external trigger events. Such trigger events are assumed to moderate the influence of persuasive external pressure on search activities by organisations. This leads to a fourth pair of conjectures:

Conjecture 4A: External trigger events moderate the impact of perceived persuasive pressure on organisational searching and scanning activities.

Conjecture 4B: External trigger events are reported more frequently by adopters than by non-adopters.

A second moderating influence stems from the activities of internal innovation champions, external knowledge brokers and exchanges of staff members:

Conjecture 5A: Knowledge gathered on personalised e-government services is spread and organisationally embedded through the activities of innovation champions, knowledge brokers and temporarily assigned staff members.

Conjecture 5B: Activities aimed at integrating the knowledge gathered within municipalities are more prevalent in adopters than in non-adopters.

All these conjectures can be synthesised into a conceptual explanatory framework (see Figure 1) which visualises how persuasive pressure is followed by specific organisational processes. The format of the framework is similar to Zahra and George's (2002) absorptive capacity (ACAP) model that generally explains organisational innovativeness. However, much more than in Zahra and George's ACAP model, the model displayed in Figure 1 acknowledges the 'push'influence of institutions through channels of persuasion, rather than 'pull'absorptive capacities (initiated by adopting organisations) emphasised by Zahra and George. Furthermore, the rendering of processes is based on a perspective that conceives of social structure and human agency as interdependent constructs (Orlikowksi and Barley, 2001) through which processes gradually enable and constrain actors in pursuing specific lines of action.

\section{--- Figure 1 somewhere here}

The line of reasoning depicted in Figure 1 combines and extends a number of previous findings in specific ways. First of all it extends and combines King et al's (1994) work on institutional influences on ICT adoption and Rogers' concept of channels of communication (see also Venkatraman et al., 1994; Leonard-Barton and Rogers, 1981; Moon and Bretschneider, 1997; Bobrowski and Bretschneider, 1994) by stipulating channels of persuasion that confront municipalities. Second, it provides an understanding of how municipalities react to persuasive pressures (i.e., by organisational searching and framing of ideas and knowledge, see 
Czarniawska and Sevon (2005)). Further, by following Orlikowski and Barley (2001), this study engages with both structure as well as agency in explaining the adoption of technologies in organisations.

\section{DISCUSSION AND CONCLUSIONS}

This paper has explored the process through which public organisations - or rather Dutch municipalities - adopt personalised e-government services. In so doing, it builds upon an institutional tradition of technology diffusion in which technology diffusion and adoption are associated with an organisation's attempts to cope with a range of prevailing norms, values, belief systems and rules that are imposed upon them, rather than primarily with individual rational cost/benefit considerations. Furthermore, an objective has been to highlight the role of human agency in the process of innovation, rather than focus on explaining the outcomes as such.

Our analysis has concentrated on persuasive environmental pressure and the ways in which knowledge and ideas regarding innovations are dealt with in municipal organisations. These concepts and their interrelationships have been conceptualised in the form of conjectures and, from these, a conceptual model of institutional influence on the adoption of personalised e-government services has been developed. Overall, the conjectures and our distilled conceptual framework show how - in this case, municipal - organisations are confronted with, and then deal with, innovations that have been strongly advocated, for example by the OECD (2009).

One notable conclusion is that municipalities are confronted with channels of persuasion that are both vertical (stemming from beyond the set of potential adopters) and horizontal (related to reputation and rivalry considerations that stem from within the set of potential adopters). The reactions prompted by this persuasive 'control' are primarily horizontally oriented: knowledge, ideas and solutions are sought from contacts within other municipalities in general, existing alliances with other municipalities in particular, and in one's own organisation.

A second conclusion is that, as Scandinavian Institutionalism argues, the 'idea' of personalised e-government is indeed actively framed, translated and transfused throughout the process of adoption by the activities of knowledge brokers, internal service champions and temporary members of staff in social integration processes. Clearly, persuasive institutional pressure and the framing of ideas and knowledge are far more important than is often acknowledged in the innovation and e-government literature streams.

These findings raise a number of questions for further research.

First, the direction and source of institutional pressures (horizontal, vertical or mixed) may depend on the differences among centralised, decentralised or decentralised unitary state regimes. Comparative research is needed to reveal differences and similarities in this respect. 
Second, the resource based view on the firm (Winter, 1987; Zahra and George, 2002) suggests that the so-called appropriability regime (the extent to which organisations are risk averse, or willing to accept ambiguities inherent in framing) moderates the relationship between framing and eventual adoption of innovations. More generally, in an era of administrative change and transformation, it is useful to remember that organisations, and the actors within them, display complex responses in attempting to promote substantive results (service delivery) and legitimacy (reputation). 


\section{REFERENCES}

Andersen, K. V., Henriksen, H. Z. (2006). E-Government Maturity Models: Extension of the Layne and Lee Model. Government Information Quarterly, 23(2), pp. 236-248.

Ashworth, R., Boyne, G., \& Delbridge, R. (2009). Escape from the iron cage? organizational change and isomorphic pressures in the public sector. Journal of Public Administration Research and Theory, 19(1), 165-187. doi:10.1093/jopart/mum038

Barney, J. (1991), Firm Resources and Sustained Competitive Advantage, Journal of Management, 17, 99-120

Bekkers, V. J. J. M., \& Homburg, V. M. F. (Eds.). (2005). The information ecology of E-government (E-government as institutional and technological innovation in public administration) (2nd ed.). Amsterdam: IOS Press.

Beynon-Davies, P., \& Martin, S. (2004). Electronic local government and the modernization agenda: progress and prospects for public service improvement. Local Government Studies. 30(2). Pp. 41-62.

Bobrowski, P., \& Bretschneider, S. (1994). Internal and external interorganizational relationships and their impact on the adoption of new technology: An exploratory study. Technological Forecasting and Social Change, 46(3), 197-211.

Bessant, J., \& Rush, H. (1995). Building bridges for innovation - the role of consultants in technology-transfer. Research Policy, 24(1), 97-114.

doi:10.1016/0048-7333(93)00751-E

Caldwell, R. (2003). Models of change agency: A fourfold classification. British Journal of Management, 14(2), 131-142.

Czarniawska, B., \& Sevon, B. (2005). Global ideas: How ideas, objects and practices travel in the global economy. Copenhagen: Copenhagen Business School Press.

Dos Santos, B., \& K. Peffers. (1998). Competitor and vendor influence on the adoption of innovative applications in electronic commerce. Information \& Management 34(3). 175-184.

DiMaggio, P. J., \& Powell, W. W. (1983). The iron cage revisited: Institutional isomorphism and collective rationality in organizational fields. American Sociological Review, 48(2), 147-160.

Esping-Andersen, G. (1990). The Three Worlds of Welfare Capitalism. Cambridge: Polity Press \& Princeton: Princeton University Press, 1990.

Frumkin, P., \& Galaskiewicz, J. (2004). Institutional isomorphism and public sector organizations. Journal of Public Administration Research and Theory. 14(3). Pp. 283-307. 
Gilbert, D., Balestrini, P., \& Littleboy, D. (2004). Barriers and benefits in the adoption of e-government. International Journal of Public Sector Management, 17(4), pp. 286-301.

Ho, A. T. (2002). Reinventing local governments and the E-government initiative. Public Administration Review, 62(4), pp. 434-444.

Holden, S. H., Norris, D. F., \& Fletcher, P. D. (2003). Electronic government at the local level. Public Performance \& Management Review, 26(4), pp. 325-344.

Homburg, V. M. F. (2008). Understanding E-government: Information systems in public administration. London: Routledge.

Homburg, V. M. F., \& A. J. D. Dijkshoorn (2011). Diffusion of Personalised EGovernment Services among Dutch Municipalities (An Empirical Investigation and Explanation). International Journal of E-Government Research. 7(3). 21-37.

Homburg, V. M. F., \& Georgiadou, Y. (2009). A tale of two trajectories: How spatial data infrastructures travel in time and space. Information Society, 25(5), pp. 303-314.

Howell, J., \& Shea, C. (2001). Individual differences, environmental scanning, innovation framing, and champion behavior: Key predictors of project performance. Journal of Product Innovation Management, 18(1), 15-27. doi:10.1016/S0737-6782(00)00067-9

Horst, M., Kuttschreuter, M., \& Gutteling, J. M. (2007). Perceived usefulness, personal experiences, risk perception and trust as determinants of adoption of egovernment services in the Netherlands. Computers in Human Behavior, 23(4), pp. 1838-1852.

Isabella, L. (1990). Evolving interpretations as a change unfolds - how managers construe key organizational events. Academy of Management Journal, 33(1), 7-41. doi: $10.2307 / 256350$

Kim, L. (1998). Crisis construction and organizational learning: Capability building in catching-up at hyundai motor. Organization Science, 9(4), 506-521.

Kimberley, J.R. (1979). Issues in the Creation of Organizations: Initiation, Innocation and Institutionalization. Academy of Management Journal. 22. 437457.

King, J., Gurbaxani, V., Kraemer, K., McFarlan, F., Raman, K., \& Yap, C. (1994). Institutional factors in information technology innovation. Information Systems Research, 5(2), 139-169.

King, S., \& Cotterill, S. (2007). Transformational government? The Role of Information Technology in Delivering Citizen-Centric Local Public Services. Local Government Studies. 33(3). Pp. 333-354.

Lai, K., Wong, C. W. Y., \& Cheng, T. C. E. (2006). Institutional isomorphism and the adoption of information technology for supply chain management. Computers in Industry, 57(1), 93-98. doi:10.1016/j.compind.2005.05.002 
Layne, K., \& Lee, J. (2001). Developing fully functional E-government: A four stage model. Government Information Quarterly, 18(2), pp. 122-136.

Leonard-Barton, E., \& E. Rogers. (1981) Horizontal Diffusion of Innovations: Alternative Paradigm to the Classical Model. Sloan School of Management Working Paper 1214, MIT, Cambridge.

Levinthal, D. A., \& March, J. G., A Model of Adaptive Organizational Search. Journal of Economic Behavior and Organization, 2 (1981) 307-333.

Ling, T. (2002). Delivering joined-up government in the UK: dimensions, issues and problems. Public Administration. 80(4). Pp. 615-642.

Lips, A. M. B., Hof, v. d., S., Prins, J. E. J., \& Schudelaro, A. A. P. (2004). Issues of online personalisation in commercial and public service delivery. Nijmegen: Wolf Legal.

Loh, L. \& Venkatraman, N. (1992). Diffusion of information technology outsourcing influence sources and the Kodak effect. Information Systems Research, 334-358.

MacDonald, S. (1995). Learning to change - an information perspective on learning in the organization. Organization Science, 6(5), 557-568.

doi:10.1287/orsc.6.5.557

Mahajan, V., \& Peterson, R. A. (1985). Models for innovation diffusion. BeverleyHills CA: SAGE.

McClure, C.R., Sprehe, J., \& Schenfelder, K. (2000). Performance Measures for Federal Agencies: Final Report. Washington DC: Defence Technical Information Center, the Energy Information Architecture, and the US Government Printing Office.

Moon, M. J. (2002). The evolution of E-government among municipalities: Rhetoric or reality? Public Administration Review, 62(4), pp. 424-433.

Moon, M. J., \& Bretschneider, S. (1997). Can state government actions affect innovation and its diffusion?: An extended communication model and empirical test. Technological Forecasting and Social Change, 54(1), 57-77.

Moon, M. J., \& Norris, D. F. (2005). Does managerial orientation matter? The adoption of reinventing government and e-government at the municipal level. Information Systems Journal, 15(1), pp. 43-60.

Miles, M. B. \& Huberman, A. M. (1994). Qualitative data analysis (2nd ed.). Thousand Oaks, CA: Sage.

Mulgan, G. (2005). Joined-up government: past, present and future. In: Bogdanor, V. (ed), Joined Up Government. Oxford: Oxford University Press. Pp. 175-189.

Norris, D. F., \& Moon, M. J. (2005). Advancing E-government at the grassroots: Tortoise or hare? Public Administration Review, 65(1), pp. 64-75. 
Orlikowski, W.J. (2000). Using Technology and Constituting Structures: A Practice Lens for Studying Technology in Organizations, Organization Science, 11, 4, 2000: 404-428.

Orlikowski, W.J. \& Barley, S. (2001). Technology and Institutions: What Can Research on Information Technology and Research on Organizations Learn from Each Other? MIS Quarterly 25(2). pp. 145-165

OECD. (2009). Rethinking e-government services (user-centred approaches). Paris: OECD.

Os, G. S. van (2011). The challenge of coordination: Coordinating integrated electronic service delivery in Denmark and the Netherlands. Information Polity, 16(1), pp 51-61.

Patton, M. Q. (2002). Qualitative Research and Evaluation Methods. Thousand oaks, CA: Sage Publications.

Pawlowski, S. D., \& Robey, D. (2004). Bridging User Organizations: Knowledge Brokering and the Work of Information Technology Professionals. MIS Quarterly. 28(4). Pp. 645-672.

Pettigrew, A.M. (1985). The Awakening Giant. Oxford, Blackwell

Pieterson, W., Ebbers, W., \& van Dijk, J. (2007). Personalisation in the public sector: An inventory of organizational and user obstacles towards personalisation of electronic services in the public sector. Government Information Quarterly, 24(1), 148-164.

Pollitt, C., \& Bouckaert, G. (2004). Public management reform: A comparative analysis. Oxford: Oxford University Press.

Reddick, C. G. (2004). Empirical models of E-government growth in local governments. E - Service Journal, 3(2), pp. 59-84.

Reddick, C. G. (2009). Factors that explain the perceived effectiveness of Egovernment: A survey of united states city government information technology directors. International Journal of E-Government Research, 5(2), pp. 1-15.

Rice, R. E., \& Rogers, E. M. (1980). Reinvention in the innovation process. Knowledge-Creation Diffusion Utilization, 1(4), 499-514.

Rogers, E. (1995). Diffusion of innovations (4th ed.). New York: Free Press.

Sahlin, K., \& Wedlin, L. (2008). Circulating ideas: Imitation, translation and editing. In R. Greenwood, C. Oliver, K. Sahlin \& R. Suddaby (Eds.), Organizational institutionalism (pp. 218-242). London: Sage.

Silva, L., \& Hirschheim, R. (2007). Fighting against windmills: Strategic information systems and organizational deep structures. MIS Quarterly, 31(2), 327-354. 
Svensson, J. (2002). Legal expert systems in social administration: From fearing computers to fearing accountants. Information Polity. 7(2,3). Pp. 143-154.

Szulanski, G. (1996). Exploring internal stickiness: Impediments to the transfer of best practice within the firm. Strategic Management Journal, 17, 27-43.

Tidd, J., Bessant, J., \& Pavitt, K. (2009). Managing innovation. Chichester: John Wiley \& Sons Ltd.

Tolbert, P. S., \& Zucker, L.G. (1996). The Institutionalization of Institutional Theory. In S. R. Clegg, C. Hardy y Walter R. Nord (Eds.), Handbook of Organization Studies (pp. 175-190). Thousand Oaks, CA: Sage.

Tyre, M. J., \& Orlikowski, W. J. (1994). Windows of opportunity - temporal patterns of technological adaptation in organizations. Organization Science, 5(1), 98-118.

Venkatesh, V., Morris, M. G., Gordon B. Davis, \& Davis, F. D. (2003). User acceptance of information technology: Toward a unified view. MIS Quarterly, 27(3), pp. 425-478.

Venkatraman, N., Lawrence Loh \& Jeongsuk Koh (1994). The Adoption of Corporate Governance Mechanisms: A Test of Competing Diffusion Models. Management Science. pp. 496-507

Van Waarden, F., \& Oosterwijk, H. (2006). Turning tracks? Path dependency, technological paradigm shifts, and organizational and institutional change. In J. T. Hage, \& M. Meeus (Eds.), Innovation, science, and institutional change. Oxford: Oxford University Press.

Wang, H., \& Doong, H. (2010). Does government effort or citizen word-of-mouth determine e-government service diffusion? Behaviour \& Information Technology, 29(4), 1-15.

Winter, S. G. (1987). Knowledge and competence as strategic assets. In D. Teece (Ed.), The competitive challenge - strategies for industrial innovation and renewal. Cambridge, MA: Ballinger.

Zahra, S. A., \& George, G. (2002). Absorptive capacity: A review, reconceptualization, and extension. The Academy of Management Review, 27(2), 185-203.

Zorn, T. E., Flanagin, A. J., \& Shoham, M. D. (2011). Institutional and Noninstitutional Influences on Information and Communication Technology Adoption and Use Among Nonprofit Organizations. Human Communication Research. 37(1). Pp. 1-33. 
Appendix A: municipalities selected for field study

Selected municipalities

\begin{tabular}{|l|l|l|}
\hline Number of inhabitants & Personalisation adopted & Personalisation not adopted \\
\hline $200,000+$ & Eindhoven & Tilburg \\
\hline $150,000-200,000$ & Enschede & Nijmegen \\
\hline $100,000-150,000$ & Haarlem & Amersfoort \\
\hline $50,000-100,000$ & Capelle aan den IJssel & Lelystad \\
\hline $0-50,000$ & Moerdijk & Lemsterland \\
\hline
\end{tabular}




\section{Appendix B: topic list for qualitative interviews}

\section{Introduction of research and researcher}

\section{Background of the respondent}

- Background (work experience), function, role in organisation

- Work environment: involvement in public services, e-government services, organisational structure, project structure, organisational environment

Origins of e-government and public services strategies, contacts regarding these issues with other municipalities, public service providers and other organisations

- Origin of ideas regarding service delivery, e-government

- Relevant internal and external stakeholders

Organisational search, learning, development

- Sources of knowledge, activities, contacts

Information strategy

- Implicit or explicit, rules, policies, key stakeholders 
Tables and figures, to be included in the text

Table 1

\begin{tabular}{|l|l|}
\hline $\begin{array}{l}\text { Determinants of e- } \\
\text { government adoption }\end{array}$ & Author(s) \\
\hline City size & $\begin{array}{l}\text { Moon (2002); Reddick (2004); Moon and } \\
\text { Norris (2005); Norris and Moon (2005); } \\
\text { Homburg and Dijkshoorn (2011) }\end{array}$ \\
\hline $\begin{array}{l}\text { Citizen demand (perceived } \\
\text { usefulness) }\end{array}$ & $\begin{array}{l}\text { Holden et al. (2003); Reddick (2004); Gilbert } \\
\text { et al. (2004); Horst et al. (2007) }\end{array}$ \\
\hline Organisational structure & $\begin{array}{l}\text { Moon (2002); Reddick (2004); Holden et al. } \\
\text { (2003); }\end{array}$ \\
\hline Geographic location & $\begin{array}{l}\text { Holden et al. (2003); Reddick (2004); Norris } \\
\text { and Moon (2005) }\end{array}$ \\
\hline $\begin{array}{l}\text { Managerial, financial and } \\
\text { technological capacity }\end{array}$ & $\begin{array}{l}\text { Reddick (2004, 2009); Moon and Norris } \\
\text { (2005) }\end{array}$ \\
\hline
\end{tabular}

Table 1: literature review of explanatory e-government studies

Table 2

\begin{tabular}{|l|l|l|l|l|}
\hline & $\begin{array}{l}\mathbf{2 0 0 6} \\
\mathbf{( n = 4 5 8 )}\end{array}$ & $\begin{array}{l}\mathbf{2 0 0 7} \\
(\mathbf{n = 4 4 3 )}\end{array}$ & $\begin{array}{l}\mathbf{2 0 0 8} \\
(\mathbf{n = 4 4 3 )}\end{array}$ & $\begin{array}{l}\mathbf{2 0 0 9} \\
(\mathbf{n = 4 4 1})\end{array}$ \\
\hline DigiD authentication & $20.7 \%$ & $56.7 \%$ & $76.3 \%$ & $88.2 \%$ \\
\hline Personalised newsletter & $16.4 \%$ & $21.2 \%$ & $21.2 \%$ & $\mathrm{~N} / \mathrm{A}$ \\
\hline Tracking and tracing & $10.0 \%$ & $16.0 \%$ & $28.2 \%$ & $26.5 \%$ \\
\hline Payment & $15.9 \%$ & $42.4 \%$ & $61.4 \%$ & $80.0 \%$ \\
\hline Pre-completed forms & N/A & N/A & $17.8 \%$ & $19.1 \%$ \\
\hline $\begin{array}{l}\text { Personalised counters } \\
\text { (MyMunicipality.nl) }\end{array}$ & $5.2 \%$ & $14.2 \%$ & $23.7 \%$ & $28.8 \%$ \\
\hline $\begin{array}{l}\text { Personalised policy } \\
\text { consequences }\end{array}$ & N/A & N/A & $19.4 \%$ & $18.7 \%$ \\
\hline
\end{tabular}

Table 2: prevalence of personalisation attributes in Dutch municipal e-government services 
Table 3

\begin{tabular}{|l|l|l|}
\hline Perceived pressures & Adopters & Non-adopters \\
\hline Citizen expectations & 56 & 36 \\
\hline Legislation & 40 & 50 \\
\hline Benchmarks & 57 & 26 \\
\hline National initiatives & 52 & 24 \\
\hline Reputation & 54 & 17 \\
\hline Other municipalities & 16 & 7 \\
\hline
\end{tabular}

Table 3: prevalence of 'pressure' on adoption decisions

Table 4

\begin{tabular}{|l|l|l|}
\hline Organisational search & Adopters & Non-adopters \\
\hline $\begin{array}{l}\text { Forums and outreach } \\
\text { programmes }\end{array}$ & 59 & 48 \\
\hline Companies & 49 & 51 \\
\hline Other municipalities & 60 & 27 \\
\hline Municipal alliances & 29 & 7 \\
\hline Own organisation & 22 & 9 \\
\hline
\end{tabular}

Table 4: organisational search 
Table 5

\begin{tabular}{|l|l|l|}
\hline Framing in terms of: & Adopters & Non-adopters \\
\hline $\begin{array}{l}\text { Service delivery, being a } \\
\text { 'service champion' }\end{array}$ & 84 & 40 \\
\hline Efficiency & 46 & 21 \\
\hline Reputation & 24 & 16 \\
\hline Management and control & 13 & 18 \\
\hline
\end{tabular}

Table 5: framing of personalised e-government services

Table 6

\begin{tabular}{|l|l|l|}
\hline Activation triggers & Adopters & Non-adopters \\
\hline $\begin{array}{l}\text { External shocks (accidents, } \\
\text { rehousing) }\end{array}$ & 17 & 4 \\
\hline Staff changes & 8 & 5 \\
\hline Organisational merger & 5 & 2 \\
\hline
\end{tabular}

Table 6: activation triggers

Table 7

\begin{tabular}{|l|l|l|}
\hline $\begin{array}{l}\text { Social integration } \\
\text { mechanisms }\end{array}$ & Adopters & Non-adopters \\
\hline $\begin{array}{l}\text { Activities of innovation } \\
\text { champions (internal) }\end{array}$ & 43 & 11 \\
\hline $\begin{array}{l}\text { Activities of knowledge } \\
\text { brokers (external experts) }\end{array}$ & 26 & 14 \\
\hline Staff exchange & 13 & 6 \\
\hline
\end{tabular}

Table 7: social integration 
Figure 1

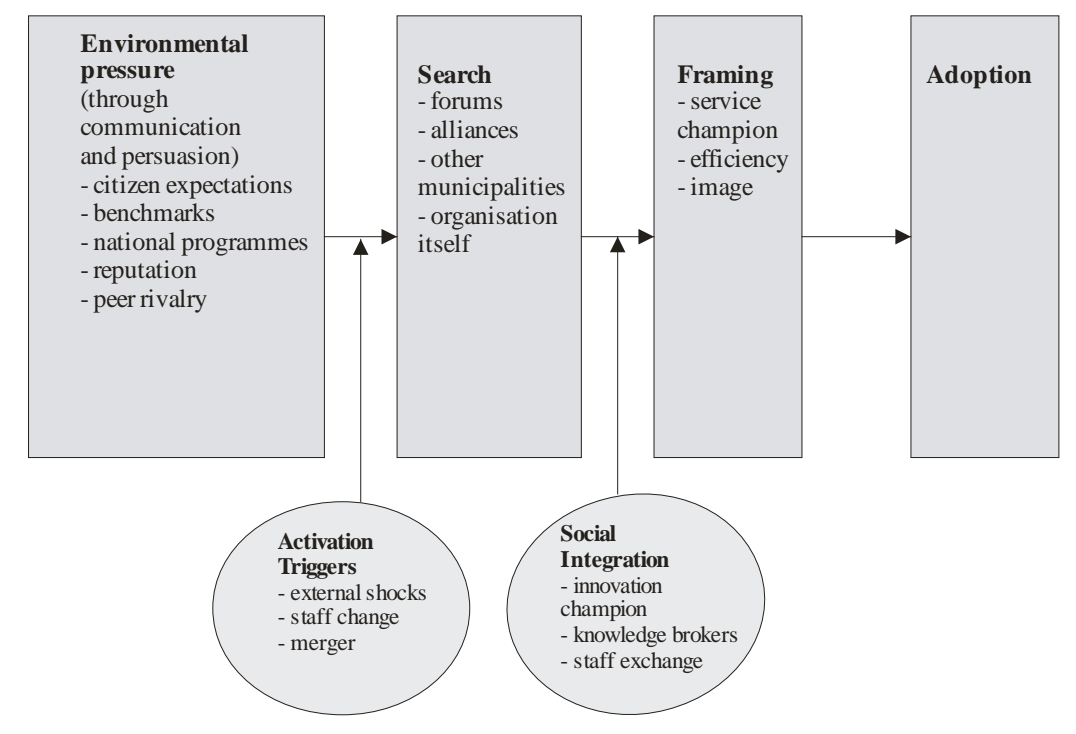

Figure 1: model of institutional influence on adoption of personalised egovernment 